\title{
Flow Injection Analysis for Trace Aluminum with On-Line Preconcentration and Spectrophotometric Detection
}

\author{
Jun Kobayashi, Miyako Baba and Motoichi MiyazakI \\ Faculty of Pharmaceutical Sciences, Kanazawa University, \\ Takara-machi, Kanazawa 920, Japan
}

\begin{abstract}
We developed a flow injection analysis method for the determination of trace aluminum in water coupled with on-line preconcentration on salicylideneamino-2-thiophenol immobilized glass beads (SAB) and spectrophotometric detection using Pyrocatechol Violet (PV). The FIA system consisted of two pumps, a 6-port switching valve, a concentrator column, a UV/VIS spectrophotometric detector and a recorder. A sample solution was combined with a succinic acid/ $\mathrm{NaOH}$ buffer ( $\mathrm{pH} \mathrm{6.0)}$ and hydroxylammonium chloride and this mixture was loaded on the concentrator column. Aluminum retained on the concentrator column was eluted with $0.1 \mathrm{~mol} \mathrm{dm}^{-3}$ nitric acid and mixed with PV. A colored PV-aluminum complex was spectrophotometrically monitored at $576 \mathrm{~nm}$. A linear relationship was observed between the peak height and aluminum concentration at a constant sample volume. A correlation coefficient of 0.9997 and determination limit of $3.7 \mathrm{nmol} \mathrm{dm}^{-3}$ were obtained for a sample volume of $10 \mathrm{ml}$. Relative standard deviations were below $2 \%$ at nmol levels. Aluminum traces in some Kanazawa City tap water samples were determined by this method.
\end{abstract}

Keywords Aluminum, trace analysis, preconcentration, flow injection, spectrophotometry, tap water

Aluminum intake has recently been recognized as a causative agent for dialysis encephalopathy, renal osteodystrophy and Alzheimer's disease..$^{1-6}$ For many years aluminum was thought to be innocuous and to pass through the gastrointestinal tract largely unabsorbed. However, acute toxicity (lethargy, anorexia, periorbital bleeding and death) after oral ingestion was documented in 1972.5,7 This has led to the development of a number of analytical methods for the determination of aluminum in drinking and environmental water samples of clinical and hygienic interest. The most commonly used analytical technique is graphite furnace atomic absorption spectrophotometry (AAS) ${ }^{8}$ Other techniques which have been employed include flow injection analysis with spectrophotometric detection ${ }^{9}$, spectrofluorometry ${ }^{10}$ and inductively coupled plasma emission spectrometry. ${ }^{11}$ However, direct determination is often limited due to interferences from the sample matrix and insufficient precision. Various separation/enrichment techniques have been used to solve these problems. ${ }^{12,13}$

We prepared salicylideneamino-2-thiophenol immobilized glass beads (hereafter, referred to as SAB; the beads, however, do not contain the mercapto group), and used them to develop a preconcentration method which retained aluminum ion selectively. ${ }^{8}$ In this paper, a FIA method for the determination of trace aluminum (ng $\mathrm{ml}^{-1}$ level) in water samples coupled with on-line preconcentration by $\mathrm{SAB}$ and spectrophotometric detection using Pyrocatechol Violet as the chromogenic reagent is reported.

\section{Experimental}

\section{Reagents}

SAB was synthesized as stated before ${ }^{8}$, using glass beads (CPG-10, $200-400$ mesh, CPG. Inc.) and salicylideneamino-2-thiophenol (SATP, Dojin Laboratories) as starting materials. An aqueous aluminum stock solution (atomic absorption spectrometric grade, $1000 \mathrm{ppm}$, $1 \mathrm{~mol} \mathrm{dm}^{-3}$ hydrochloric acid) was purchased from Wako Pure Chemical Industries and diluted appropriately with water before use. A $1.0 \mathrm{~mol} \mathrm{dm}^{-3}$ succinic acid $/ \mathrm{NaOH}$ buffer ( $\mathrm{pH} 6.0$ ) was prepared by dissolving $4.7 \mathrm{~g}$ of succinic acid monosodium salt (Nacalai Tesque) and $48.0 \mathrm{~g}$ of disodium salt (Nacalai Tesque) in $200 \mathrm{ml}$ of water and filtering the mixture through a membrane filter (pore size: $0.45 \mu \mathrm{m}, \mathrm{FM}-45$, Fuji), before suitable dilution. A Pyrocatechol Violet stock solution $(0.1 \%)$ was prepared by dissolving $0.1 \mathrm{~g}$ of Pyrocatechol Violet (PV, Dojin; without purification) in $100 \mathrm{ml}$ of water and diluting 10-times with the $0.5 \mathrm{~mol} \mathrm{dm}^{-3}$ succinate buffer before use. The hydroxylammonium chloride and nitric acid used were heavy metal analysis grade reagents (Wako Pure Chemical Industries). All water used was distilled and deionized with a Milli-Q II system (Millipore). All other reagents used were of special grade. 


\section{Preparation of aluminum sample solutions}

Sample solutions were made up using $0.01 \mathrm{~mol} \mathrm{dm}^{-3}$ succinic acid/ $\mathrm{NaOH}$ buffer (pH 6.0) and 0.1\% hydroxylammonium chloride immediately before use.

\section{Apparatus}

Aluminum used in preliminary tests and all other metals were determined by a polarized Zeeman atomic absorption spectrometer (Z-8000, Hitachi). The pH readings and conductivity were obtained using a $\mathrm{pH}$ meter (PH82, Yokogawa) and a conductivity meter (DS14, Horiba), respectively. All glasswares were prepared by immersion for $24 \mathrm{~h}$ in dilute nitric acid, followed by rinsing in water.

\section{Instrumentation}

A systematic diagram of the on-line analysis system used this study and the basic procedure are shown in Fig. 1 and Table 1. This FIA system consisted of two pumps (JASCO 880 -PU), a 6-port switching valve (JASCO Column Selection Unit 892-01), a plastic column packed with $\mathrm{SAB}(50 \times 4.6 \mathrm{~mm}$ i.d.; $\mathrm{SAB}, 0.47 \mathrm{~g})$, a UV/VIS spectrophotometric detector (JASCO 870$\mathrm{UV} ; 576 \mathrm{~nm}$ ), a column oven (JASCO 860-CO; $40^{\circ} \mathrm{C}$ ), a reaction coil $(5 \mathrm{~m} \times 0.5 \mathrm{~mm}$ i.d.; PTFE tubing) and a recorder (Shimadzu C-R1B). PTFE and polypropylene

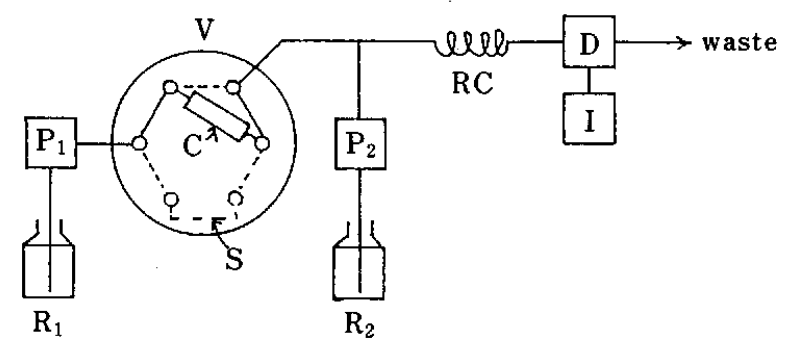

Fig. 1 Schematic diagram of on-line analysis system for $\mathrm{Al}^{3+}$. $\mathrm{P}_{1}, \mathrm{P}_{2}$ : pumps; $\mathrm{R}_{1}$ : reservoir 1 (sample or $0.1 \mathrm{~mol} \mathrm{dm}^{-3}$ nitric acid); V: 6-port switching valve; $\mathrm{C}$ : concentrator column $(50 \times 4.6 \mathrm{~mm}$ i.d.; packed with SAB $(0.47 \mathrm{~g}))$; $\mathrm{S}$ : short-circuit line; $\mathrm{R}_{2}$ : reservoir 2 (Pyrocatechol Violet in $0.5 \mathrm{~mol} \mathrm{dm}^{-3}$ succinate (pH 6.0)); RC: reaction coil $(5 \mathrm{~m} \times 0.5 \mathrm{~mm}$ i.d., $40^{\circ} \mathrm{C}$ ); D: UV-VIS spectrophotometric detector $(576 \mathrm{~nm})$; 1 : recorder. tubing were used as much as possible, and $0.1 \mathrm{~mol} \mathrm{dm}^{-3}$ nitric acid and water were passed through before use.

\section{Tap water samples}

We obtained some tap water samples for FIA. Conductivity and $\mathrm{pH}$ of sample solutions were measured immediately after sampling. Particulate matter was removed using a membrane filter $(0.45 \mu \mathrm{m}, \mathrm{FM}-45$, Fuji) and $0.1 \mathrm{~mol} \mathrm{dm}^{-3}$ nitric acid was added to the filtrate before storing in a refrigerator $\left(5^{\circ} \mathrm{C}\right)$. The filtrate was

Table 2 Characteristics of tap water

\begin{tabular}{|c|c|c|c|}
\hline $\begin{array}{l}\text { Sample } \\
\text { number }\end{array}$ & pH & $\begin{array}{c}\mathrm{EC} / \\
\mu \mathrm{S} \mathrm{\textrm {cm } ^ { - 1 }}\end{array}$ & $\begin{array}{l}\text { Concentrations of } \\
\text { several metals }\end{array}$ \\
\hline 1 & 7.94 & 234.5 & $\begin{array}{l}\mathrm{Fe}, 15.6 \mathrm{ppb} ; \mathrm{Mn}, 9.3 \mathrm{ppb} \\
\mathrm{Pb},<2 \mathrm{ppb} ; \mathrm{Cu}, 0.9 \mathrm{ppb} \\
\mathrm{Ni},<1 \mathrm{ppb} ; \mathrm{Mg}, 3.4 \mathrm{ppm} ; \\
\mathrm{Ca}, 12.5 \mathrm{ppm} ; \mathrm{Na}, 26.2 \mathrm{ppm}\end{array}$ \\
\hline 2 & 7.58 & 73.7 & $\begin{array}{l}\mathrm{Fe}, 28.8 \mathrm{ppb} ; \mathrm{Mn}, 0.5 \mathrm{ppb} \\
\mathrm{Pb}, 9 \mathrm{ppb} ; \mathrm{Cu}, 9.0 \mathrm{ppb} \\
\mathrm{Ni},<1 \mathrm{ppb} ; \mathrm{Mg}, 1.5 \mathrm{ppm} ; \\
\mathrm{Ca}, 6.3 \mathrm{ppm} ; \mathrm{Na}, 13.7 \mathrm{ppm}\end{array}$ \\
\hline 3 & 7.50 & 85.7 & $\begin{array}{l}\mathrm{Fe}, 36.5 \mathrm{ppb} ; \mathrm{Mn}, 0.9 \mathrm{ppb} \\
\mathrm{Pb},<2 \mathrm{ppb} ; \mathrm{Cu}, 3.5 \mathrm{ppb} \\
\mathrm{Ni},<1 \mathrm{ppb} ; \mathrm{Mg}, 1.4 \mathrm{ppm} \\
\mathrm{Ca}, 4.4 \mathrm{ppm} ; \mathrm{Na}, 20.0 \mathrm{ppm}\end{array}$ \\
\hline 4 & 7.34 & 82.6 & $\begin{array}{l}\mathrm{Fe}, 37.8 \mathrm{ppb} ; \mathrm{Mn}, 1.9 \mathrm{ppb} \\
\mathrm{Pb}, 8 \mathrm{ppb} ; \mathrm{Cu}, 12.5 \mathrm{ppb} \\
\mathrm{Ni},<1 \mathrm{ppb} ; \mathrm{Mg}, 1.3 \mathrm{ppm} \\
\mathrm{Ca}, 4.3 \mathrm{ppm} ; \mathrm{Na}, 19.2 \mathrm{ppm}\end{array}$ \\
\hline 5 & 7.59 & 84.2 & $\begin{array}{l}\mathrm{Fe}, 9.7 \mathrm{ppb} ; \mathrm{Mn}, 0.8 \mathrm{ppb} \\
\mathrm{Pb}, 3 \mathrm{ppb} ; \mathrm{Cu}, 7.9 \mathrm{ppb} \\
\mathrm{Ni},<1 \mathrm{ppb} ; \mathrm{Mg}, 1.6 \mathrm{ppm} ; \\
\mathrm{Ca}, 6.2 \mathrm{ppm} ; \mathrm{Na}, 15.8 \mathrm{ppm}\end{array}$ \\
\hline 6 & 7.43 & 78.8 & $\begin{array}{l}\mathrm{Fe}, 15.0 \mathrm{ppb} ; \mathrm{Mn}, 1.1 \mathrm{ppb} \\
\mathrm{Pb},<2 \mathrm{ppb} ; \mathrm{Cu}, 5.7 \mathrm{ppb} \\
\mathrm{Ni}, 2.0 \mathrm{ppb} ; \mathrm{Mg}, 1.6 \mathrm{ppm} \\
\mathrm{Ca}, 6.1 \mathrm{ppm} ; \mathrm{Na}, 13.7 \mathrm{ppm}\end{array}$ \\
\hline 7 & 7.65 & 97.7 & $\begin{array}{l}\mathrm{Fe}, 5.7 \mathrm{ppb} ; \mathrm{Mn},<0.5 \mathrm{ppb} \\
\mathrm{Pb},<2 \mathrm{ppb} ; \mathrm{Cu}, 7.8 \mathrm{ppb} \\
\mathrm{Ni},<1 \mathrm{ppb} ; \mathrm{Mg}, 1.6 \mathrm{ppm} ; \\
\mathrm{Ca}, 8.1 \mathrm{ppm} ; \mathrm{Na}, 14.5 \mathrm{ppm}\end{array}$ \\
\hline
\end{tabular}

EC: conductivity. Sample numbers are the same as in Fig. 7. Among the detected metals, $\mathrm{Mn}, \mathrm{Pb}, \mathrm{Cu}, \mathrm{Ni}$ and $\mathrm{Mg}$ give positive errors in spectrophotometric determination.

Table 1 Basic procedure of $\mathrm{Al}^{3+}$ determination

\begin{tabular}{|c|c|c|c|c|}
\hline Step & Time $/ \mathrm{min}$ & Pump $1^{\mathrm{a}}$ & Valve position ${ }^{\mathbf{a}}$ & Purpose of step \\
\hline 1 & $0-t$ & 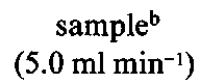 & solid & load $\mathrm{Al}^{3+}$ onto concentrator column \\
\hline 2 & $t-t+10$ & $\begin{array}{c}\text { water } \\
\left(1.0 \mathrm{ml} \mathrm{min}^{-1}\right)\end{array}$ & solid & flush the column and tubing of non-retained aluminum \\
\hline 3 & $t+10-t+18$ & 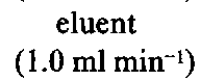 & dotted & back-flush $\mathrm{Al}^{3+}$ from the column, clean up, and start recorder \\
\hline 4 & $t+18-t+28$ & 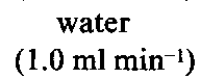 & dotted & stop recorder, rinse with nitric acid to stand by for next sample \\
\hline
\end{tabular}

$t$ : aluminum sample loading time. Eluent: $0.1 \mathrm{~mol} \mathrm{dm}^{-3}$ nitric acid. a. System diagrams (pump 1 and valve) were the same as Fig. 1. Pump 2 was left for delivering color agent (contained buffer and PV) at $1.0 \mathrm{ml} \mathrm{min}^{-1}$. b. This sample was already treated with a buffer and a reducing agent. 


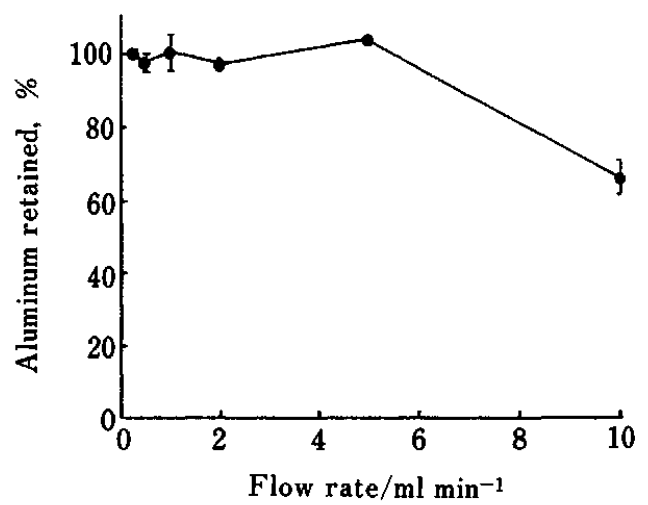

Fig. 2 Effect of flow rate on retention of $\mathrm{Al}^{3+}$. Sample: $100 \mathrm{ml}$ of $\mathrm{Al}(10 \mathrm{ppb}) ; 0.01 \mathrm{M}$ succinate $(\mathrm{pH} 6.0)$ and hydroxylammonium chloride $(0.5 \mathrm{~g})$ added. Data were averaged from 3 determinations.

divided in order to determine concentrations of several metals by AAS. The results are shown in Table 2 . The residue was made weakly acidic by the addition of $\mathrm{NaOH}$ and treated as stated in "Preparation of aluminum sample solutions" just before analysis.

\section{Results and Discussion}

Effects of several conditions on the retention/elution of aluminum

The effects of several system conditions on retention and elution of aluminum from SAB were investigated. Examination of the $\mathrm{Al}^{3+}$ sample solution flow rate in the preconcentration stage is summarized in Fig. $2 ; \mathrm{Al}^{3+}$ was almost completely retained in the 0.5 to $5.0 \mathrm{ml} \mathrm{min}^{-1}$ region. A sample solution flow rate of $5.0 \mathrm{ml} \mathrm{min}^{-1}$ in the preconcentration stage was chosen for the analytical procedure. A $0.1 \mathrm{~mol} \mathrm{dm}^{-3}$ nitric acid was selected as the column eluent for the following reasons: 1) it would not prevent colorimetric determination of aluminum; 2) rapid elution of $\mathrm{Al}^{3+}$ from the $\mathrm{SAB}$ column; and 3) lower contamination from the system.

\section{Color reagent}

Selection of an appropriate color reagent and investigation of optimum detection conditions were performed. Since aluminum is selectively concentrated by $\mathrm{SAB}$, the reagent does not have to have a specific color development for aluminum. A sensitive color reagent, Pyrocatechol Violet was chosen for the following reasons: 1 ) it is water soluble; 2 ) it has a rapid complexing rate with aluminum; 3) its absorption spectrum is different from that of the aluminum complex; and 4) it has a large molar absorption coefficient at the detection wavelength. PV-aluminum complexes have an absorption maximum at $576 \mathrm{~nm}$ and $\varepsilon$ (molecular extinction coefficient) of $5.5 \times 10^{4}$.

To minimize aluminum contamination from the laboratory environment and to shorten the analytical procedure, postcolumn reaction was performed after

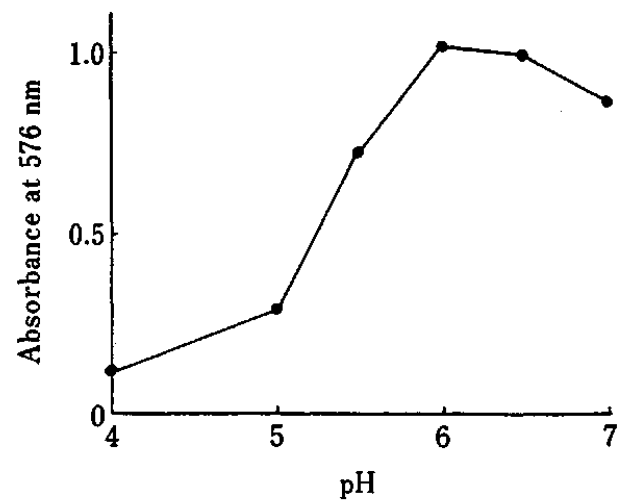

Fig. 3 Effect of $\mathrm{pH}$ on absorbance. Sample: $5 \mathrm{ppm} \mathrm{Al} \mathrm{(0.5}$ $\mathrm{ml})+0.1 \mathrm{M}$ acetate $(5 \mathrm{ml})+0.05 \% \mathrm{PV}(0.5 \mathrm{ml})$. Reaction temperature: r.t. Reaction time: $10 \mathrm{~min}$. Blank: reagent only.

Table 3 Effect of buffer species on absorbance

\begin{tabular}{|c|c|c|c|}
\hline \multirow{2}{*}{ Buffer species } & \multicolumn{3}{|c|}{ Absorbance at $576 \mathrm{~nm}$} \\
\hline & Sample & Blank & Sample-Blank \\
\hline Succinic acid/NaOH & 1.035 & 0.067 & 0.968 \\
\hline Propionic acid/NaOH & 1.005 & 0.041 & 0.964 \\
\hline Acetic acid/ $\mathrm{NH}_{3}$ & 0.938 & 0.036 & 0.902 \\
\hline Pyridine $/ \mathrm{HNO}_{3}$ & 0.937 & 0.045 & 0.892 \\
\hline Acetic acid/NaOH & 0.816 & 0.037 & 0.779 \\
\hline Piperazine $/ \mathrm{HNO}_{3}$ & 0.850 & 0.082 & 0.768 \\
\hline Isobutyric acid/NaOH & 0.614 & 0.036 & 0.578 \\
\hline HEPES/NaOH & 0.040 & 0.023 & 0.017 \\
\hline Imidazole $/ \mathrm{HNO}_{3}$ & 0.036 & 0.028 & 0.008 \\
\hline Citric acid/NaOH & 0.065 & 0.061 & 0.004 \\
\hline
\end{tabular}

Sample: 5 ppm Al $(0.5 \mathrm{ml})+0.1 \mathrm{M}$ buffer $(\mathrm{pH} 6.0,5.0 \mathrm{ml})+$ $0.05 \%$ PV $(0.5 \mathrm{ml})$. Reaction temperature: r.t. Reaction time: 10 min. Blanks were measured at the same time, without Al. HEPES: 2-[4-(2-hydroxyethyl)-1-piperazinyl]ethanesulfonic acid.

aluminum was eluted from the column. The postcolumn solution consisted of a PV stock solution and buffer, this simplified FIA manipulation. Absorbance was measured at $576 \mathrm{~nm}$ for aluminum against a reagent blank.

As shown in Fig. 3 and Table 3, a succinic acid/ $/ \mathrm{NaOH}$ (pH 6.0) postcolumn buffer gave a maximum absorbance value. Pyrocatechol Violet concentration was decided to be $0.005 \%$ (final) by $\varepsilon$ value. The PV reagent was added in excess. The composition of the complex formed under analytical conditions was estimated by the molar ratio method to be $1: 2$ (metal: reagent). When the PV solution was delivered at the same flow rate as the eluent, buffer concentration above $0.5 \mathrm{~mol} \mathrm{dm}^{-3}$ was needed to maintain $\mathrm{pH}$ 6.0. When more concentrated buffer than $0.5 \mathrm{~mol} \mathrm{dm}^{-3}$ was used, the linearity of calibration curve was lost. On the other hand, when more alkaline and dilute buffers were used, a reduction in absorbance was observed, which seems to be due to the decomposition of PV. ${ }^{14}$ As a result, $0.5 \mathrm{~mol} \mathrm{dm}^{-3}$ succinic acid $/ \mathrm{NaOH}$ (pH 6.0) was used. 


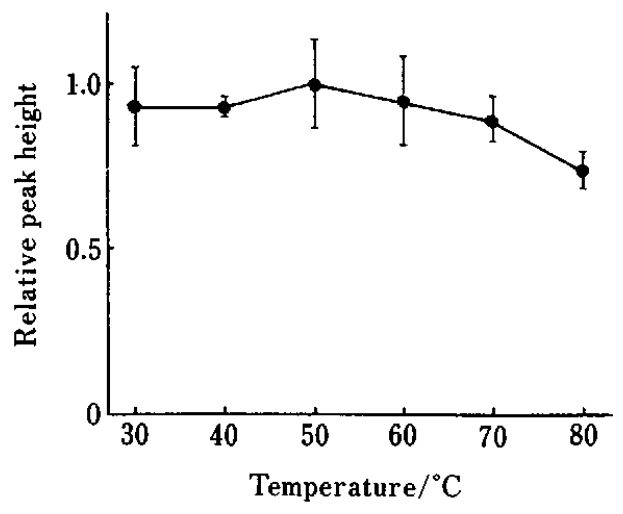

Fig. 4 Effect of temperature on absorbance. Sample: $15 \mathrm{ml}$ of Al $(10 \mathrm{ppb}) ; 0.01 \mathrm{M}$ succinate $(\mathrm{pH} 6.0)$ and $0.1 \%$ hydroxylammonium chloride added. Data were averaged from 3 determinations.

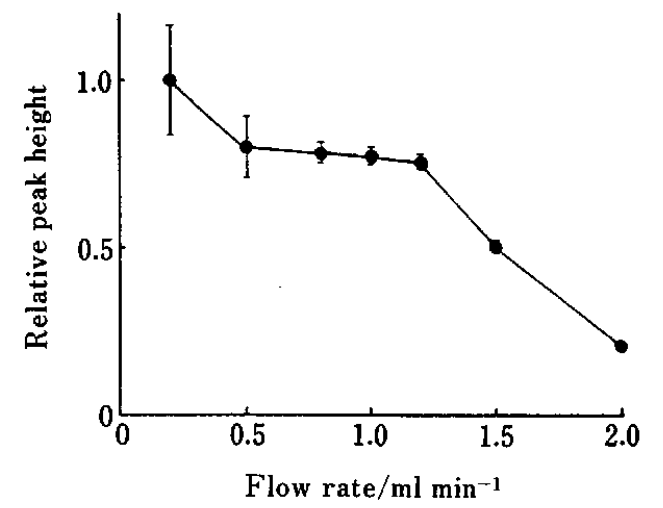

Fig. 5 Effect of flow rate on peak height. Sample: $15 \mathrm{ml}$ of $\mathrm{Al}(10 \mathrm{ppb}) ; 0.01 \mathrm{M}$ succinate $(\mathrm{pH} 6.0)$ and $0.1 \%$ hydroxylammonium chloride added. Data were averaged from 3 determinations.

\section{Postcolumn reaction conditions}

The reaction of aluminum ion with Pyrocatechol Violet was investigated with regard to reaction temperature and time. The reaction time was varied by changing the dimensions of the reaction coil and the flow rate of the pumps. Under a fixed conditions $(10 \mathrm{~m} \times$

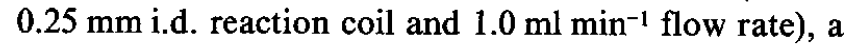
reaction temperature of $40^{\circ} \mathrm{C}$ gave better reproducibility, as shown in Fig. 4. On the other hand, pump flow rates and reaction coil features were also investigated at a fixed temperature $\left(40^{\circ} \mathrm{C}\right)$, as shown in Fig. 5: maximum peak height was obtained at $0.2 \mathrm{ml} \mathrm{min}^{-1}$ but reproducibility was bad. The noise level hardly changed at any flow rate. At a fixed flow rate of $1.0 \mathrm{ml} \mathrm{min}-1,10 \mathrm{~m} \times$ $0.25 \mathrm{~mm}$ i.d., $5 \mathrm{~m} \times 0.5 \mathrm{~mm}$ i.d. and $2.5 \mathrm{~m} \times 0.5 \mathrm{~mm}$ i.d. reaction coils were tried, with the second coil proving to be the best. This was thought to be due to a greater reaction time and mixing efficiency. No further investigation of the reaction coil was carried out.

\section{Introduction of a 6-port valve}

Under all the experimental conditions studied above, a linear relationship exists between aluminum concentra-

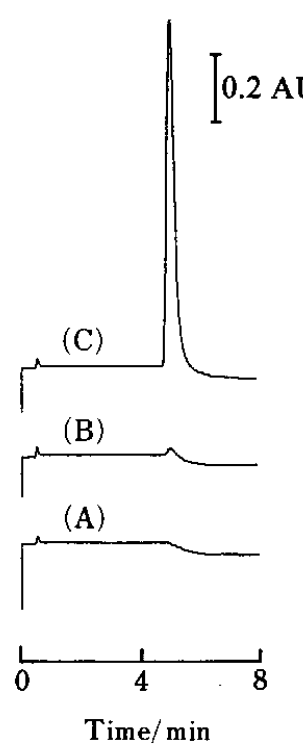

Fig. 6 Typical FIA peak of $\mathrm{Al}^{3+}-\mathrm{PV}$ chelate. Sample: $50 \mathrm{ml}$ of $\mathrm{Al} ; 0.01 \mathrm{M}$ succinate $(\mathrm{pH} 6.0)$ and $0.1 \%$ hydroxylammonium chloride added. Al concentration: (A) and (B), $0 \mathrm{ppb}$; (C), 10 ppb. (B) and (C) were stored in $0.1 \mathrm{~mol} \mathrm{dm}^{-3}$ nitric acid and adjusted to a near neutral $\mathrm{pH}$ using sodium hydroxide just before analysis. (A) was prepared just before analysis and did not contain nitric acid and sodium hydroxide.

Table 4 Effect of sample volume on peak height

\begin{tabular}{ccc}
\hline Sample volume $/ \mathrm{ml}$ & Slope $/ \mathrm{AU}_{\mu \mathrm{g}^{-1}}$ & Intercept/AU \\
\hline 10 & 1.08 & 0.069 \\
20 & 1.09 & 0.080 \\
50 & 1.08 & 0.117 \\
100 & 1.09 & 0.155 \\
\hline
\end{tabular}

AU: absorbance unit. All slopes were calculated by peak heights (AU)/Al loaded ( $\mu \mathrm{g})$, and intercepts were calculated by peak heights (AU), where $\mathrm{Al}$ concentration $=0$. All intercepts are approximated by the following equation: $0.062+0.001 \times$ sample volume $(\mathrm{ml})$.

tion and peak area. However, no such relationship exists between aluminum concentration and peak height. Since this linear relationship applies to various loading volumes, the peaks broadened at high loading volume. We thought this was a problem not to detectable few aluminum. We assumed that this is due to retention of aluminum ions occurring only at the front of the SAB column, thereby causing the retention volume (peak width) to change when they diffuse down the column at elution and/or retention steps. Back-flushing can solve this problem, so we introduced a 6-port valve into the FIA system to permit back-flushing. The 6-port valve was tubed with a short-circuit line and the system was arranged so as to allow carrier flow to continually pass through the detector, as shown in Fig. 1.

\section{Analytical characteristics}

Typical FIA peaks were shown in Fig. 6. A linear 


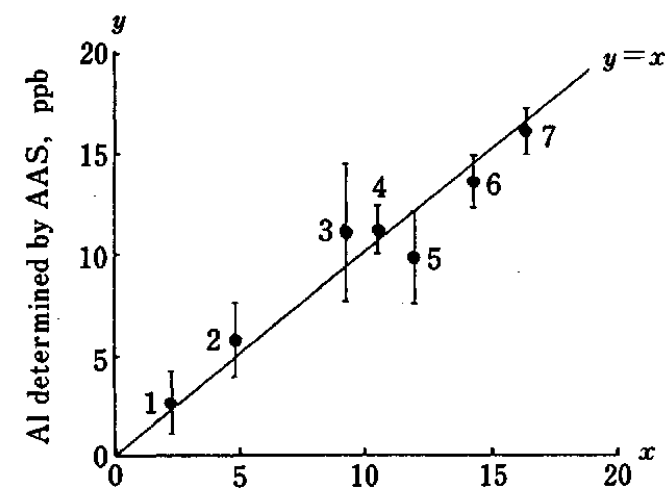

Al determined by this study, ppb

Fig. 7 Determination of $\mathrm{Al}$ in tap water. Sample volume: $20-30 \mathrm{ml}$ (this study) and $20 \mu \mathrm{l}$ (AAS). Data were averaged from 3 determinations. Standard deviations are shown as $x$ (this study)- and $y$ (AAS)-bars. Sample numbers are the same as in Table 2.

relationship was observed between peak height and the amount of aluminum in the range $0-500 \mathrm{ng}$. The correlation coefficient was 0.9997 and the determination limit $(S / N=3) 3.7 \mathrm{nmol} \mathrm{dm}^{-3}(0.1 \mathrm{ppb})$, for a $10 \mathrm{ml}$ sample volume. Relative standard deviation $(n=3)$ were below $2 \%$ at the nmol level $(0.9 \%$ at $25 \mathrm{ppb} ; 1.5 \%$ at $50 \mathrm{ppb}$ ). This linearity was also achieved at other sample loading volumes for these experimental conditions and each calibration curve was linear. The blank consisting of the same volume of reagent was determined on the same day. Several samples containing the same amount of aluminum were compared at different loading volumes. Calibration curves had the same slopes, but not the same intercepts (Table 4).

\section{Water analysis}

Aluminum in some Kanazawa City tap water samples was determined by the present FIA method. Generally, tap water is considered to contain aluminum at very low levels and to contain many interfering substances. As shown in Fig. 7, aluminum concentrations at the ppb level were determined, despite the presence of many other ions. Determined values $(1,2.28 \pm 0.01 ; 2,4.84 \pm 0.04 ; 3$, $9.29 \pm 0.12 ; 4,10.58 \pm 0.07 ; 5,11.98 \pm 0.06 ; 6,14.31 \pm 0.08$; $7,16.42 \pm 0.05 \mathrm{ppb}$ as shown in Fig. 7) were in good agreement with direct graphite furnace-AAS analysis. In future work, we are going to apply this method to samples with a more complicated matrix, such as seawater.

\section{References}

1. O. Wada, "Kinzoku to Hito-Ecotoxicology to Rinsho (Metal Elements and Human Beings; with Emphasis of Clinical Ecotoxicology in Japanese)," p. 233, Asakura Shoten, Tokyo, 1985.

2. S. Morita, Seikatsu Eisei, 34, 199 (1990).

3. A. R. Brody, Science [Washington, D.C.], 208, 297 (1980).

4. E. Kaneko, H. Hoshino, T. Yotsuyanagi, N. Gunji, M. Sato, T. Kikuta and M.Yuasa, Anal. Chem., 63, 2219 (1991).

5. M. Kawahara and Y. Kuroda, Gendai Iryo, 24, 1769 (1992).

6. J. P. Landsberg, B. McDonald and F. Watt, Nature [London], 360, 65 (1992).

7. J. B. Eastwood, G. E. Levin, M. Pazianas, A. P. Taylor, J. Denton and A. J. Freemont, Lancet, 336, 462 (1990).

8. J. Kobayashi and M. Miyazaki, Chem. Pharm. Bull., 41, 919 (1993).

9. A. Prownpuntu and U. Titapiwatanakun, Analyst [London], 116, 191 (1991).

10. P. Fernandez, C. P. Conde, A. Gutierrez and C. Camara, Talanta, 38, 1387 (1991).

11. A. Taylor and A. W. Walker, Ann. Clin. Biochem., 29, 377 (1992).

12. K. Hayakawa, J. Kobayashi, M. Ohmori, M. Ohya, A. Kato and M. Miyazaki, Anal. Sci, 9, 419 (1993).

13. J. Kobayashi, H. Yamada, M. Morishita and T. Yajima, Anal. Sci., 9, 821 (1993).

14. K. L. Cheng, K. Ueno and T. Imamura, "Handbook of Organic Analytical Reagents," p. 35, CRC Press, Boca Raton, 1982. 